\title{
The Implementation of The Authority Of Mandatory Government Affairs Related To Basic Services In The Province of West Java Year 2014-2017
}

\author{
Nandang Alamsah Deliarnoor \\ The Department of Government Science Padjadjaran University \\ Hernadi Affandi \\ The Department of Law Padjadjaran University \\ Dede Sri Kartini \\ The Department of Government Science Padjadjaran University \\ Neneng Yani Yuningsih \\ The Department of Government Science Padjadjaran University
}

Suryanto

The Department of Business Administration Padjadjaran University

Sony Ahmad Nulhaqim

The Department of Social Welfare Padjadjaran University

Mas Halimah

The Department of Public Administration Padjadjaran University

\begin{abstract}
Law No. 23 of 2014 about regions that government affairs are divided into absolute affairs, concurrent connections affairs and general government affairs. Concurrent affairs are joint affairs that are divided into the authority of the central, provincial and regional governments and become the basis of the implementation of local autonomy. The purpose of this research is to examine the implementation of the authority of the government in administering concurrent connections affairs, especially mandatory affairs related to basic services. This research method utilizes qualitative approach and to examine normative jurisdiction. This research reveals that whilst the implementation of local autonomy for 13 years has brought forth a number of positive changes to the community, it still lacks in both regulations and its implementation. One of the aspects that need to be addressed and clarified is the limitation of the authority of government given to provinces and regions.
\end{abstract}

Keywords: local government, government authority, local development, West Java

\section{INTRODUCTION}

Indonesia is a unitary state that according to Article 18 of the 1945 Constitution amendment is divided into provinces, which are further divided into regencies and municipalities. Every province, regency and municipality has regional government to control and manage its own government affairs on the basis of local autonomy and assisting role. The implementation of central, provincial and regional government authority is based on the division of government affairs. According to Law No. 23 of 2014 about Regional Government, government affairs are 
divided into absolute affairs, concurrent connections affairs and government affairs general. Concurrent connections affairs are joint affairs that are divided into the authority of the central, provincial and regional governments. In the implementation of concurrent connections affairs, the authority is distributed to the central government, the provincial government and the regional government.

In the context of the law of good governance, the legal standing (rechpositie, legal positions) of the provincial government in the implementation of local autonomy remains unclear, hence the difficulty of being able to carry out its functions and duties well. On the one hand, a governor becomes head of the an autonomous region that must be running its own regional government affairs; on the other, a governor is a representative of the central government in the region, although it is not clear what authority has been given to such position and what must be done to carry out its function as the representative of the central government. Generally, legislation only asserts that the authority of the central government is given to a governor as a function of coordination of the implementation of local autonomy, supervision function, control and development function of the regional government in the regencies/municipalities.

In the context of local autonomy and local development, the implementation of local autonomy is considered not ready because even though the regions are given freedom of administering affairs that have been handed to them, that authority is not accompanied by the assignment of financial resources; central control over the process of the development of the regions is still very high, in addition to the presence of some bad governance practices that are still done by regions, so the implementation of local autonomy has not yet achieved its aim.

Psychologically, changes to the system of government by providing a greater portion of authority to the regions resulted in symptoms of 'powershift syndrome', in which the central government prior to imposing local autonomy had such authority, but as the policy on local autonomy began to take effect, central government was deemed 'powerless' before the regional government. This authority shift may cause any potential conflicts between the central and regional governments. First, the possible conflict between the governor, regents and mayors with the local parliament. Second, the potential conflict between the central and regional governments (Chalid, 2005: 10-11). The hierarchy of the relations between the central and regional governments may ignite conflict as a result of the transfer of authority to the regions. Law No.22/1999 provides the regional/municipal governments a great authority. With such great authority, there arises the perception among regional officials that they are no longer bound and subject to central government in provincial level. Therefore, often a regent/mayor does not answer to a governor's invitation to the provincial capital citing being kept busy in the region and the absence of fund as excuses. Whereas in Law No.22/1999 prior to its amendment which is Law No. 32/2004, a governor still performs a function of coordination. For the governor, certainly the authority he had exercised shifted greatly when Law No. 5/1974 which granted him extensive authority began to take effect. Moreover, the concept of "Governor as a single ruler" imposed by the Minister of Domestic Affairs Amir Machmud asserted that the authority of a governor is very superior.

Although the implementation of local autonomy for 13 years has brought forth a number of positive changes to the community in the area and promoted the welfare of the community in the area, but there is still a lack of good regulations and practices in field. Legislation of local autonomy namely Law No. 32/2004 is viewed as no longer in accordance with the dynamics of the needs of the governance of the growing regional government. Then, the Indonesian government also issued Law No. 23 of 2014. But what needs to be addresses and clarified is the authority of government given to provinces and regencies/municipalities. 
The clarity of the authority given to the provincial and regional/municipal governments, as mentioned in Article 12 of Law No. 23 of 2014, needs to be thoroughly addressed by the government. The implementation of government concurrent connections affairs, both the mandatory and optional affairs, still brings about problems that cannot be solved by either the inter-governments or within the government itself. The complete lack of authority; authority arbitrariness; authority overlap; half-hearted authority; authority takeover; arbitrary or abused authority and the lack of authority impose problems in the implementation of the authority of mandatory government affairs related to basic services, such as in the field of a. education; b. health; c. public works and spatial planning; d. settlement and housing; e. public peace and order, and protection of society; and f. social affairs. In addition to 6 (six) basic services that become collective affairs, another example of the problem of the authority is the management of marine natural resources between the province and regions based on Article 27 of Law No. 23 of 2014.

Nonetheless, the issue of the division of government affairs between the central, provincial and regional/municipal governments is the most crucial issue in the implementation of local autonomy. Changes to the policy on local autonomy on Law No. 23 of 2014 in fact still cause uncertainty regarding the boundaries of the authority of the central and regional governments. This shows that the policy on local autonomy in Indonesia does not have a clear pattern yet. On regional level, the lack of a clear pattern impacts on the implementation of the regulation being confusing. It becomes interesting to turn to scientific studies to find out whether the enactment of Law No. 23 of 2014 will resolve the issue of the relations of central and regional authority or the contrary, thus this research aims to discuss the implementation of the authority of the provincial government in administering affairs of concurrent connections i.e. mandatory affairs related to basic services.

\section{RESEARCH METHODS}

This research uses qualitative research method approach, which explains in detail and provides in-depth analysis related to the implementation of the authority of the government in the context of unitary state and the implications of the delegation of authority on the implementation of provincial and regional authority in administering local autonomy and local development to promote the welfare of the citizens of the community in the area, especially in West Java. The use of qualitative research method is considered appropriate because it exercises the power of reason of empiric phenomenon that does not involve only one but numerous factors that can explain many things about the model of relations of authority of a unitary state, the delegation of authority, the implementation of local autonomy, local development and community welfare in the regions. In addition this research also uses normative juridical approach, an approach that is done based on the main legal materials by examining theories, concepts, principles of law and legislation related to this research.

The analysis units of this research are the institutions of the Government of West Java province and its subsidiary regional/municipal governments, among others: Office of Education of West Java Province, Office of Health of West Java Province, Office of Highways and Spatial Planning of West Java Province, Office of Settlement and Housing of West Java Province, Office of Social Affairs of West Java Province.

The data that is required in this research consists of two types of data, namely primary data and secondary data. Primary data is data/information obtained directly from informants/experts who understand the problem of the research. Primary data can be 
obtained through interview and Focus Group Discussion (FGD). Secondary data is data that has been processed in the form of figures or facts.

Qualitative data analysis techniques used in this research consist of three flows of main activities that occur simultaneously, namely: data reduction, data presentation, withdrawing of conclusion. From the analysis, author conducts an interpretation of the data on the research that does not solely aim to describe but also provide explanations by developing further analysis on general description of the research. In the case of testing the validity of the data, following stages are done:

1. Triangulation of data and data sources; data has been collected through interviews from a variety of sources of informants consisting of government officials, citizens of community, members of groups of interest, and experts who understand the problem of the research. Triangulation is also done through various observations and analysis of documents and its interconnection pattern will be examined.

2. An examination by a member or an informant (member check) which serves as an audit throughout the analysis process to ensure the validity of the data that is given.

3. The long-term and repetitive observations in the location of the research.

4. Cross examination by colleagues.

In the analysis, this research also reviews legislation including: the 1945 Constitution and Law No. 23 of 2014 about Regional Government.

\section{The contents of the results and Discussion}

\section{RESULTS AND DISCUSSION}

Mandatory government affairs related to basic services address 6 (six) affairs, namely Education, Health, Public Works and Spatial Planning, Settlement and Housing, Public Peace and Order and Protection of Society, and Social Affairs. In addition to the six offices that deal directly with mandatory government affairs related to basic services, there is one provincial authority of managing marine natural resources. Therefore the affair of each office shall be explained briefly below. In accordance with the Law No. 23 of 2014, the implementation of mandatory affairs related to basic services is compulsory in all regions. Thus, each level of government has the authority in accordance with the mandate of the law.

\section{The implementation of the authority of the Office of Education on the implementation of local autonomy and local development especially in West Java}

In the perspective of local autonomy, West Java Province as an autonomous region has the authority to control and manage education affairs. Thus this section will discuss how the Office of Education of West Java Province implements the authority in accordance with the regulations and how it manages education affairs.

The government has set the Law No. 20/2008 on National Education System (Law On National Education System) and Law No. 221999 which then changed to Law No. 32/2004 (Act on Regional Government) so that the management and the implementation of the national education system in the form of decentralization can be realized between central and regional governments in harmony and equality which is beneficial for all the people of Indonesia in the frame of the Unitary State of the Republic of Indonesia) ${ }^{1}$. In accordance with Law No. 23 of

1 https://siapbelajar.com/pemprov-jabar-ambil-alih-pengelolaan-sma-dan-smk-mulai-2-mei-2016/ hours 11.36 April 11 October 2017 
2014 about Regional Government, education affairs become government concurrent connections affairs as well as the basis of the implementation of local autonomy.

In response to affairs of concurrent connections in education, the Provincial Government of West Java has issued Local Regulation No. 5 of 2017 about the implementation of education which is a refinement of Law No. 7 of 2008. Below will be described how education management, curriculums, educators and educational staff are arranged and administered.

\section{Education Management}

Education Management is understood as the administration of education, so that the administration of education is defined by the Local Regulation No. 5 of 2017 as arrangement of authority in conducting national education system by the Government, Provincial Governments, Regional/Municipal Governments, education providers established by the community and educational units in order for the education process to take place in accordance with the purpose of national education. In regard to education management, Office of Education of West Java Province is authorized to regulate the secondary education, special education and special service education.

Secondary education is advanced level education which consists of general secondary education and vocational education in the form of High School (Sekolah Menengah Atas/SMA); Extraordinary High School (Sekolah Menengah Atas Luar Biasa/SMALB); Madrasah Aliyah (MA), the Islaming schooling equivalent of SMA; Vocational High School (Sekolah Menengah Kejuruan/SMK); Madrasah Aliyah Vocational School (Madrasah Aliyah Kejuruan/MAK), the Islamic equivalent of SMK under the management of the Ministry of Religious Affairs; High School Equivalency (Kejar Paket C) Program or other forms of the equal level. Whereas special education is the type of education on basic and secondary levels for students who experience difficulty to participate in the learning process because of physical, emotional, mental, or social disabilities and/or have extraordinary intelligence and gifts.

Special education is done through special education units and units of inclusive general education. Special education units are intended for students with disabilities and/or have extraordinary intelligence and gifts. The units of special education for students with disabilities include:

a. Early Age Education (Pendidikan Anak Usia Dini/PAUD) units, in the forms of Extraordinary Kindergarten (Taman Kanak-Kanak Luar Biasa/TKLB) and other similar and equal forms;

b. Basic education units such as Extraordinary Primary School (Sekolah Dasar Luar Biasa/SDLB) and Extraordinary Junior High School (Sekolah Menengah Pertama/SMPLB) or other similar and equal forms;

c. Secondary education units such as Extraordinary Senior High School (Sekolah Menengah Atas Luar Biasa/SMALB) or other similar and equal forms.

Special education units for learners who have the potential of extraordinary intelligence and/or gifts cover both basic and secondary education units including primary and secondary schools for the gifted. This special education unit can conduct special education integrated between education levels and/or between the types of intelligence.

Meanwhile inclusive education is the education service system on every education unit that accommodates all learners without discrimination, with the services provided in accordance 
with the conditions and the needs of the learners in the closest environment with their house. Inclusive education units include:

a. Kindergarten / Raudhatul Athfal (RA), the Islamic schooling equivalent of kindergarten;

b. Primary school / Madrasah Ibtidaiyah (MI), the Islamic schooling equivalent of primary school and junior high school / Madrasah Tsanawiyah (MTs), the Islamic schooling equivalent of junior high school;

c. Senior high school / Madrasah Aliyah (MA) and vocational high school / Madrasah Aliyah Kejuruan (MAK).

The education units that provide special education for learners who have the potential for extraordinary intelligence and/or gifts with inclusive education service system include:

a. Primary school / MI and junior high school / MTs; and

b. Senior high school / MA and vocational high school / MAK.

Special service education is a type of special education which is conducted for learners who have difficulties to participate in the learning process because of social circumstances such as residing in remote or underdeveloped areas, being members of remote indigenous communities, experiencing natural disaster and social disaster, getting into trouble with the law, and not being financially capable. Special service education through open schools is held for learners who cannot follow the formal education on regular basis due to time constraints and/or having to help with their family economy.

The authority that is given to the Office of Education is considered better, because the management of education especially the secondary, special and special service becomes more organized. The regional and municipal governments focus more on the affairs of primary and secondary education while the provincial governments focus on the three education units. Now that the provincial government has taken over the burden of funding, it is expected that the regional/municipal governments that have always strongly funded high schools will gradually lessen the privilege. Before secondary education was managed by the provinces, many regencies/municipalities claimed to be funding high schools even though the funding was actually done by the provincial government.

Since high schools have been put under the authority of the Head of West Java Province, there will no longer be top senior high schools, because the infrastructures and the quality of the teachers will be equalized, and the budget from the provinces will focus on the matter. However, there is a budget management habit that needs to be changed, namely the management of grants. Grants used to be identical with assistance funding, which meant they were readily available and handed to the secondary education first and planning was proposed afterwards. On the contrary, nowadays the planning must be proposed first before the grants will be awarded. Thus the schools must plan their activities and then file the proposed plan.

\section{The curriculum}

The curriculum is a set of plans and arrangements regarding the purpose, the contents and teaching materials and methods that are used as guidelines for the implementation of learning activities to achieve specific learning goals. The provincial government develops national curriculum and the curriculum of local contents on the secondary, special, and special service education units. The development of national curriculum refers to graduates competency standard, contents standard, process standard and evaluation standard in accordance with legislation. The development of the local content curriculum includes language, literature, arts, values of history, noble values, traditions, local cultures and characters to implement education 
in provinces with reference to the SNP. In regard to the curriculum and the local contents, there considered to be no problems, since each region has its own potential.

\section{Educators and Educational Staff}

Educators on secondary education, special education and special service education units include: Teachers; Counselor; Study guardian; Tutor; Instructor. Whereas educational staff include: School Supervisors and Principals; Librarians; Laboratory assistants; School administrative staff; and other workers who support the activities in education units.

The provision of educators and educational staff needed by the provincial government is carried out by the Local Employment Agency based on the results of the Regional Staffing Equity conducted by the Office of Education. Meanwhile, the province also facilitates the fulfillment of the qualification and competence of the educators and educational staff on secondary education, special education and special service education units in order to balance the implementation of quality education.

Facilitation of competency of the educators is prioritized for educators on special education units and special service education units on open schools and distance learning system through development and training. Then the Technical Executive Unit under the Office of Education will carry out the development and the training.

Funding for the implementation of education is a joint responsibility of the Central Government, the Provincial Government and the community. The provincial government provides $20 \%$ of the fund from the regional government budget, whilst the financing of the education events conducted by the community is done independently by the organizer. The source of education funding by the Provincial Government can originate from: State Budget (Anggaran Pendapatan dan Belanja Negara/APBN), Regional Government Budget (Anggaran Pendapatan dan Belanja Daerah/APBD) of West Java Province, and other valid sources.

Education providers established by communities can be funded by: education units formed by the community; assistance from people who are not the learners or their parents/guardians; the aid of the Central and the Provincial Government; unbinding aid from foreign party; business results of organizers or education units; and/or other valid sources.

In spite of the transfers, teachers in the regions prefer to move into the city. Since the inauguration of teachers as civil servants in 2009 until now there has been no more recruitment, which means that automatically the number of teachers holding the status as civil servants keeps decreasing. The high numbers of honorary teachers becomes a liability for the province and burdens the Employment Agency.

The equity of welfare for teachers in secondary education, special education and special service education units was also made possible because of the takeover by the Province. Teachers in all West Java Regions receive the maximum allowance of Rp. 1,000,000, but this condition is in contrast with the teachers in the City of Bekasi and Karawang Regency, who would deem such arrangement a setback, since initially before being redeployed they could manage more than Rp. 1,000,000.

In implementing this education authority there are things that need to be further regulated such as inclusive education, the curriculum, the standard of education and the development of 
local and national curriculum that require the Governor Regulation, whereas special service education practitioners require the Governor's Decree.

\section{The implementation of the authority of the Office of Health on the implementation of local autonomy and local development especially in West Java}

The Development of National Health aims to increase awareness, willingness and ability to live a healthy life for everyone so that optimum degree of community health can be obtained. Such ideal is characterized by each member of the population living in a healthy environment, behaving healthy, having the ability to access a quality health service and the willingness to obtain optimum personal health level (Health Ministry of The Republic Of Indonesia, 2004.)

Health indicators that can provide an illustration of the degree of community health include Life Expectancy (Angka Harapan Hidup/AHH), mortality rate such as mother and infant mortality rate and the morbidity namely the incidents or the prevalence of infectious diseases as well as non-contagious diseases.

Life Expectancy (Angka Harapan Hidup/AHH) is one of the indicators of government performance in improving the welfare of the population in general, especially in promoting the optimum degree of community health. An increase in AHH indicates an improvement in the welfare of the citizens which also means a higher health degree of the nation's people.

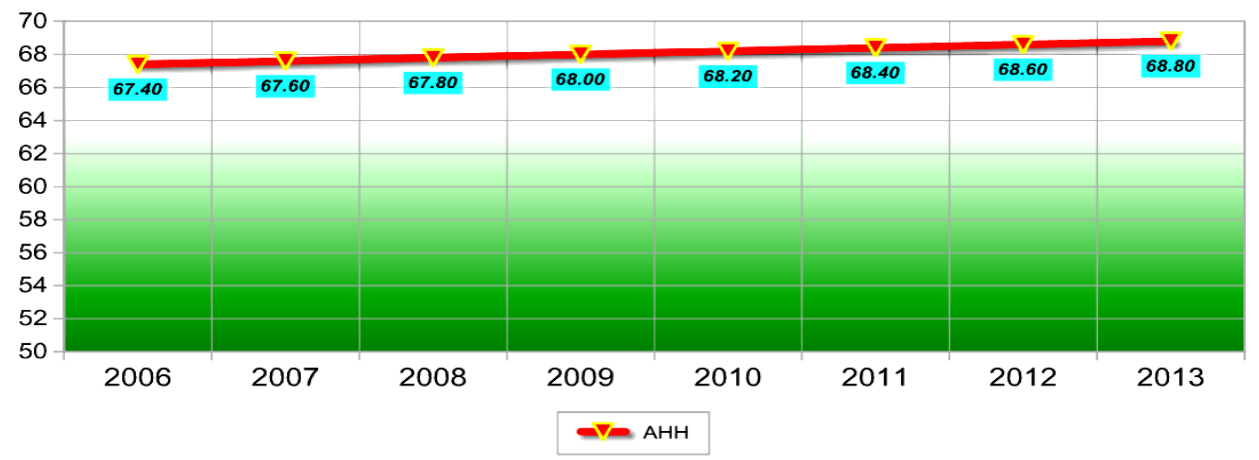

Graphic 1 Tendency of Life Expectancy (Angka Harapan Hidup/AHH) for Population in West Java Province 2008 - 2013

Based on Statistics Indonesia (Biro Pusat Statistik/BPS)'s data of West Java, Life Expectancy $(\mathrm{AHH})$ in West Java in 2013 was 68.80. The tendency of AHH of West Java Province from year to year increased. By comparing the figures of AHH 2009 to AHH 2013, it can be seen that AHH in West Java Province during the period of 2009 - 2013 increased by 1 point. On average it increased by 0.2 point annually. With an AHH increase of 0.2 year each year, it means that to obtain an $\mathrm{AHH}$ increase of 1 year it will require 5 years.

Obtaining a long and healthy AHH requires attention to the input condition; the average first age of marriage, basic sanitation facilities (toilets and usable drinking water sources), the availability of health facilities and health workers. The condition of the process includes access to health assistance, health behavior (the number of visits to the clinic and hospital and the number of children being immunized).

Routine reporting and recording system produces the information in the form of absolute figures or with comparison ratio of mortality rate and the number of newly born babies.

The Maternal Mortality Rate (MMR) describes the national representative and is one of the indicators of community health degree. According to Indonesian Demographic and Health 
Survey (Survei Demografi dan Kesehatan Indonesia/SDKI) 2007, Indonesia has successfully reduced MMR from 390/100,000 live births in 1992 to 334/100,000 live births in 1997. According to the data from the Ministry of Health in the year 2008, MMR fell to 228/100,000 live births. But based on SDKI 2012 MMR increased to 359/100,000 live births.

Based on a report from the Regional Office of Health, the Maternal Mortality Rate in West Java tends to decrease each year. In 2013, 781 cases of maternal deaths were reported. The number was lower compared to 2011 and 2012, in which 850 deaths and 804 deaths were reported respectively.

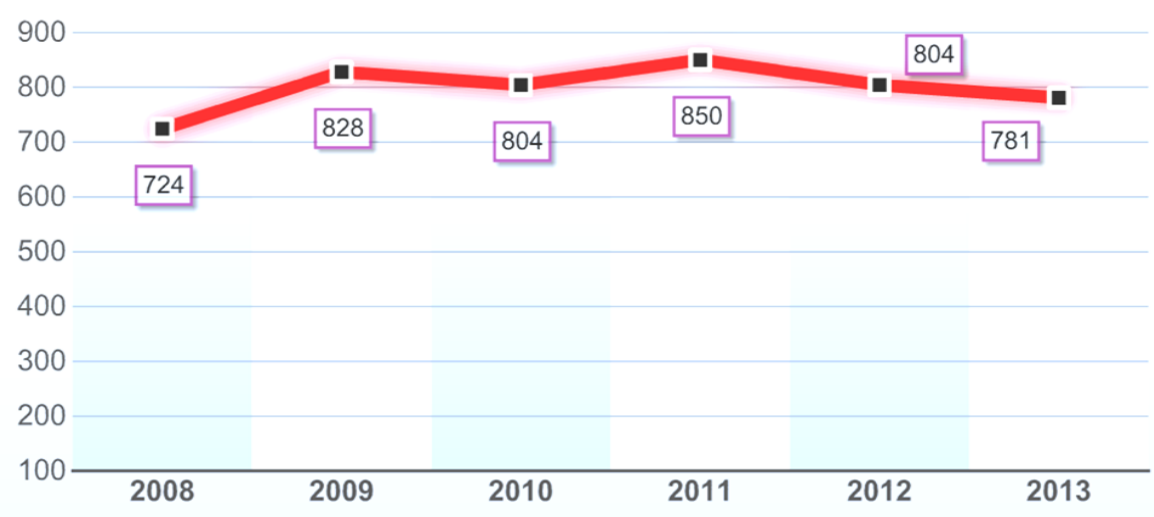

\section{Graphic 2 the Number of Maternal Deaths in West Java 2008 - 2013}

Infant mortality rate (IMR) presented that provincial scale. Based on SDKI 2012, the IMR of West Java Province in 2012 was 30/1000 live births. Compared to IMR of 2008 (38.5/1000 live births), there had been a decrease of 8.5 point.

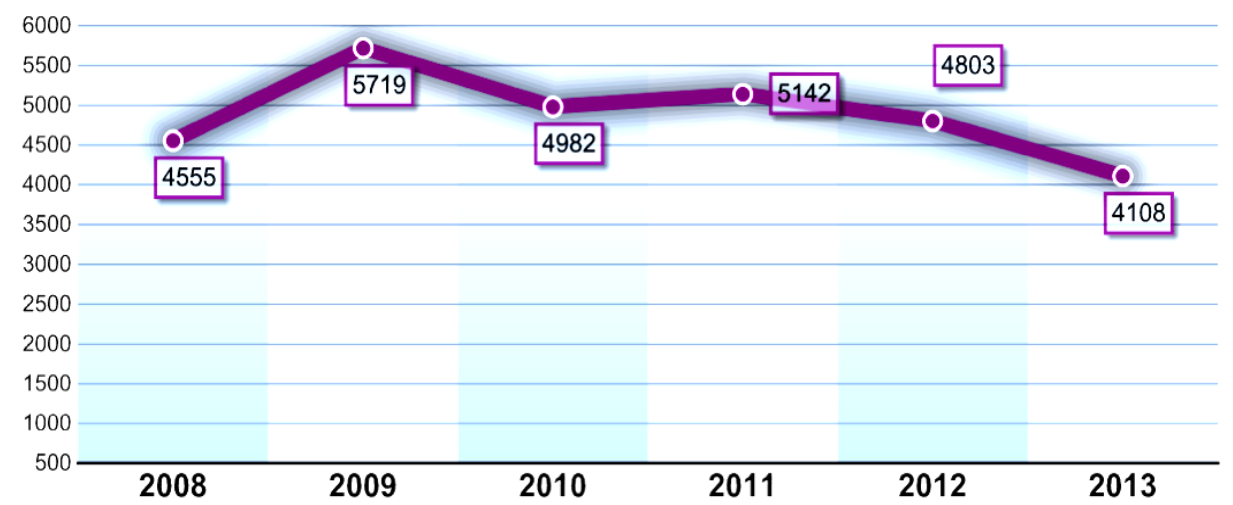

Graphic 3 Number of Infant Deaths in West Java 2008 - 2013

Based on a report from the Regional Office of Health, since 2009 - 2013 the number of infant deaths tends to decrease each year. In 20134306 infant deaths were reported, approximately 1601 less than in 2009. The calculation of the infant death ratio by comparing the number of infant deaths with the number of live births in 2012 was recorded at 5.2/1000 live births (kelahiran hidup/KH) and down to 5.0/1000 KH in 2013 (a drop of 0.2 point). Based on SDKI 2012 the infant death ratio in West Java was 30/1,000 live births.

The high prevalence of malnutrition in infants is one of the risk factors that have an impact on the lack of human resources in the future (lost generation). The prevalence of malnutrition in West Java Province in the period 2008 - 2012 showed the tendency to decrease, although from 
2011 to 2012 there was an increase of 0.1 percent from $0.82 \%$ in 2011 to $0.83 \%$ in 2012, and it decreased again in 2013 to $0.76 \%$.

Problems associated with several diseases that affect efforts to obtain increased Life Expectancy include: non-contagious and some other infectious diseases that occur in West Java.

The results of public health service consist of health services for high risk groups especially maternal and child health services, disease control, health staff resources, health facilities and infrastructure, whereas health service for children includes disease control, immunization services and nutrition program.

\section{The implementation of the authority of the Office of Highways and Spatial Planning on the implementation of local autonomy and local development especially in West Java}

Office of Highways and Spatial Planning of West Java Province tends to have very clear authority. In this sector, the main affair of the Office is the roads. The provincial authority of the roads includes the construction of provincial roads. The roads are divided into national roads, provincial roads, regional/municipal roads and village roads. The clearest authority on this sector is under the jurisdiction of Office of Highways. There are differences between the types of roads. First of all, the roads connecting one province to another are called primary arterial roads and are national roads. The roads connecting one region to another or connecting provinces to regions are primary collector roads. These types of roads are regulated by decrees. The decree on national roads is issued by the Ministry of Public Works, on provincial roads by the Governors, and on regional/municipal roads by the Regents or the Mayors. Second, in accordance with the status specified by the mayor, the Office cannot deal with the roads specified for the municipalities since the Office authorities over the province and the rule is clear. There is no problem regarding the authority.

In a case where the Office wants to manage roads that are considered by the province as strategic locations for tourism spots or industries which can develop the regions, the provincial government cannot do so if the roads fall under the regional/municipal government authority. Such issue can be solved by the provincial government providing financial assistance to the regional/municipal government and letting the regional/municipal government to manage the roads since the authority to do so still lies within their jurisdiction. In regard to roads, there have been no changes to Laws and Government Regulations on this matter.

The village authority proves a difficult obstacle. There are no problems in the provincial levels. Village roads are within the village authority. Yet in Government Regulations on Roads it has never been explicitly stated. In a case where the regional governments try to interfere with the management of village roads, they will be subject to the Audit Board of Indonesia (Badan Pemeriksa Keuangan/BPK)'s audit since the authority of managing village roads resides with village governments. The problem is whether the villages have the adequate personnel, human resources and managerial capacity to manage the roads by themselves, and whether they will be able to take part should the construction of village roads be put out to tender. There is also a possible issue in supervising. The cost of village roads construction is exorbitant and it involves a large budget, and it remains to be seen whether the villages have the capability of managing and supervising the budgets. Therefore, the village governments need to consider taking the following steps:

a. Strengthen the village forces

b. Improve the village resources' capability (human resources, office resources, and other resources). 
The village authority must be not only implemented but also strengthened by regulations, including Law No. 23 of 2014 or other relevant laws. The village governments must not feel burdened by these mandatory affairs just because the regional governments cannot provide assistance since it will be subject to BPK's audit.

The weakness lies on either Law No. 23 of 2014 or its implementation. If Law No. 23 of 2014 states that the authority must be exercised by the village governments, then there needs to be reinforcement of village resources to ensure that the personnel will be capable of managing not only the village roads construction but also other sectors such as economy and culture. If it is not feasible, it can be re-arranged so that the authority for village roads goes to the regional governments.

Financial assistance for the villages can be for mosque or irrigation system construction. Whether the villages have the capability to manage such assistance, and whether it is regulated on Law No. 23 of 2014 needs to be analyzed. Perhaps there needs to be limitation regarding aids for the villages after taking the villages' resources into considerations. Not all sectors can go into the villages and the funds should also be regulated. The amount of workload involved must also not exceed the villages' capacity since they may not have sufficient resources to handle such heavy workload. If it is handed over to an outside contractor, there is a possibility of the job not being done properly and the village personnel not being aware of it.

Next, in regard to spatial planning affairs, it is clear that the Office has the authority over organizing spatial planning in provincial level. In addition, in the case of suspended bridge construction, it is to be understood that such construction is full of risk and needs precise calculation. If villages are given the assistance to do the construction while the personnel do not have sufficient knowledge to do it, the construction cannot be done properly and the bridge may collapse. When it happens, there will enquiries about who should take the responsibility. This example illustrates the weakness in the regulation, since the boundaries of authority are not clearly stated and there are no clear arrangements about who is responsible for which sector. Furthermore, the regulations do not seem to take the circumstances in the regions/villages into account.

The model of authority is necessary to analyze not only the division of authority on each level but also its capability to manage government affairs. When the village governments are deemed not capable to implement their authority, then the regional government may take over. This is due to the fact that not all villages are ready for the mandatory affairs assigned to them. There are no problems with the sector construction service, as there is no overlap. However, since the service is still new so it remains to be seen if there will be possible overlaps in the future.

Furthermore, the authority of the Office of Highways is also related with the management of the sea, in which marine spatial planning must follow the procedures for land spatial planning. Thus, coordination with other related offices is required in managing the marine spatial planning.

\section{The implementation of the authority of the Office of Housing and Settlement on the implementation of local autonomy and local development especially in West Java} There are two mandatory affairs administered by the Office of Housing and Settlement of West Java Province, namely the affairs of public works and spatial planning, and the affairs of housing and settlement areas. In interpreting its authority, the Office is still trying to determine 
its organizational structure. Although there has been a change of name, from previously Office of Settlement and Housing to Office of Housing and Settlement, but there are no changes regarding the affairs that it needs to take care of, nor are there any additional affairs.

In the implementation stage, the problem lies on the achievement of Minimum Service Standard (Standar Pelayanan Minimum/SPM). Law No. 23 of 2014 states that provincial department only administers the affairs of housing and settlement areas. In the calculations there are three equations in the calculation of housing: first, the scope of livable house; second, the scope of livable and affordable house, and; three, the scope of a healthy and safe environment that is supported by infrastructure, facilities and utilities (Prasarana, Sarana dan Utilitas/PSU). The problem is in the calculation of the house only one equation can be used. Thus, the target is not achieved because the calculations cannot be properly done. The center government enquires why the figures do not appear, but the regulations do not define affordable so the provincial office cannot determine what deems a house affordable and is only able to do the calculation using one equation out of possible three that must be reported to the central government, which is the scope of livable house.

In regard to other targets, they can actually be calculated and are achievable. For affairs of public works such as drinking water, waste water and waste, being able to calculate is already considered good enough. Although the targets may still be underachieved, they are better than the housing affairs.

It remains to be seen whether Law No. 23 of 2014 is actually better since the Organizational Structure and Working Procedure (Struktur Organisasi dan Tata Kerja/SOTK) has only been put into effect and evaluated for one year, which means that it may need some adjustments. The regulation will be better but the Office requires adjustments with the new governance now. In general, it can be said that there should be more details about the works. There needs to be a clear the division of authority and an arrangement of which office handles which affair. Although there are some that may intersect, such as the Office of Housing and Settlement Affairs with the Department of Environment in the affairs of waste. When this occurs, the tasks will overlap, but in the future hopefully such circumstance can be resolved.

The implementation of government affairs of housing and settlement areas by the Office of Housing and Settlement of West Java Province involves both physical and non-physical activities. The physical activities mean constructions, and in regard to affairs of public works they cover drinking water, waste water sanitation, waste, and drainage. Each involves physical and non-physical workload. This means that every affair is implemented in two ways, physical and non-physical. The authority of the provincial government is in the physical activities such as construction. In the case of drinking water affairs, the authority covers regional scale, which means that water needed in regions/municipalities shall be the responsibility of the provincial government, including the construction of Drinking Water Supply System (Sistem Penyediaan Air Minum/SPAM) all the way to the landfill (Tempat Pembuangan Akhir/TPA). The nonphysical aspects of the affairs include planning before the Environmental Impact Analysis (Analisis Mengenai Dampak Lingkungan/AMDAL) and supervision.

The implementation of affairs of certification, qualification, classification, and the registration of the housing and settlement areas as well as the certification of builders through training, but now the authority of the affairs has been transferred to the Office of Highways. 


\section{The implementation of the authority of the Office of National Unity and Community Protection on the implementation of local autonomy and local development especially in West Java}

Law No. 23 of 2014 Article 25 states that General Government Affairs include:

a. fostering national awareness and national defense in order to strengthen the implementation of Pancasila, the implementation of the Constitution of the Republic of Indonesia Year 1945, the preservation of unity in diversity and preservation and maintenance of the integrity of the Unitary Republic of Indonesia;

b. fostering national unity;

c. fostering harmony of intertribal, religious, racial and other groups to achieve security stability of local, regional, and national levels;

d. social conflict resolution in accordance with the legislation;

e. coordinating the implementation of the tasks of government agencies that exist in the provinces and in the districts/cities to solve problems that arise with regard to the principle of democracy, human rights, equity, justice, privilege and specificity, potency and regional diversity in accordance with the provisions of the legislation;

f. development of democracy based on Pancasila; and

g. implementation of all Government Affairs that is not a regional authority and not implemented by the vertical institutions.

Moreover, as stated in the verse (3) in Article 25, to carry out the general government affairs, governors and regents/mayors are assisted by vertical institutions. Vertical institutions are related to the implementation of deconcentration principle. In this case, Office of National Unity and Politics of West Java Province exists as a vertical institution that helps governors and regents/mayors to carry out general government affairs. The appointment of the Office of National Unity and Politics as the vertical institution that holds hierarchical authority directly from the Central Government through the Ministry of Home Affairs is the latest decision as a result of enactment of Law No. 23 of 2014 especially Article 25 about General Government Affairs $^{2}$. The change consequently means that all forms of authority and policies issued by the Office of National Unity and Politics of West Java Province are free from the intervention of the governor, but in terms of coordination and supervision, the governor still has the authority to do both as an extension of the Central Government ${ }^{3}$.

Since the status change took place, the Office of National Unity and Politics of West Java Province is no longer funded by Regional Government Budget (Anggaran Pendapatan dan Belanja Daerah/APBD) of West Java Province but by the State Budget (Anggaran Pendapatan dan Belanja Negara/APBN). The change to a vertical institution also positions the Office of National Unity and Politics of West Java Province as a partner of the Government of the Province of West Java, the same as other vertical institutions in the regions ${ }^{4}$.

After previously being under the authority of the Regional Government, the Office of National Unity and Politics has changed its status as a vertical institution under the Ministry of Home Affairs due to some considerations. One of them is the effectiveness of the reporting procedures and control over the tasks and functions of the institution which is considered very

\footnotetext{
${ }^{2}$ http://kesbangpol.kemendagri.go.id/index.php/subblog/read/2016/5250/2017-Badan-Kesbangpol-jadiInstansi-Vertikal/2327

${ }^{3} \mathrm{Http}: / /$ www.mysultra.com/tahun-2018-kesbangpol-sultra-jadi-instansi-vertikal/

${ }^{4}$ Https://www.antarariau.com/berita/70901/kewenangan-berpindah-ke-pemerintah-pusat-pegawaikesbangpol-jangan-khawatirkan-mutasi.
} 
crucial and important as they include political, security, social culture, society and economic analysis affairs. The tasks and functions make the Office of National Unity and Politics as a strategic institution whose related position as a vertical institution must be rearranged in order to strengthen the presidential government system in Indonesia. Some even argue that the strategic role of the Office is becoming increasingly important given that the issues and events regarding radicalism, terrorism and separatism need to be detected early and dealt with more seriously5.

In the Strategic Planning 2010-2014, the vision of Directorate General (Direktorat Jenderal/Ditjen) of National Unity and Politics of the Ministry of Home Affairs of the Republic of Indonesia is "the actualization of the unity of the nation through a democratic political system in the framework of the Unitary State of the Republic of Indonesia".

To realize the vision, Directorate General of National Unity and Politics formulates the missions of the as follows:

1. Maintain and strengthen the integrity of the Unitary State of the Republic of Indonesia.

2. Strengthen the political system in a democratic country in the Unitary State of the Republic of Indonesia.

3. Strengthen national insights, ideology and national awareness, assimilation of the nation, awareness and capabilities of nation's defense, and insights into the economic resilience in the political, social, culture and law order of all citizens, supported by roles of social and cultural institutions of the society for the reinforcement of social integration.

As a breakdown of the vision and missions, the Directorate General of National Unity and Politics sets the goal of "strengthening the unity and national unity and domestic political stability that is based on the spirit and values of Pancasila and the Constitution through the development of a democratic political system and the sovereignty of the people". Furthermore, as derivations from the goal, the Directorate General of the National Unity and Politics specifies four strategic targets that will be achieved in the Strategic Planning 2010-2014:

1. Increasing the quality of the implementation process of democracy (Election/Presidential Election).

2. Increasing the commitment of stakeholders in maintaining the unity of the nation.

3. Increasing communication and constructive dialog between members of the community in solving various problems of the community.

4. Increasing awareness of citizens in political participation.

\section{The implementation of the authority of the Office of Social Affairs on the implementation of local autonomy and local development especially in West Java}

The problem faced by the Office of Social Affairs of West Java Province on the implementation of the authority as stated on Law No. 23 of 2014 Article 30 is "the province must allocate adequate funding through Regional Government Budget (Anggaran Pendapatan dan Belanja Daerah/APBD) to take care of the poor". This becomes a contradiction and causes confusion about who the authority of alleviating poverty and taking care of the poor belongs to. On their campaign prior to election, each candidate of Regional Head always promises to carry out programs that will seek to alleviate poverty. As a matter of fact, if it is tracked back up, poverty alleviation lies under the authority of the central government. But in the end, the provincial and regional governments must provide funding to take care of the poor people in the provinces and districts/cities.

${ }^{5} \underline{\text { Http://rakyatsulsel.com/kesbangpol-efektif-jika-dijadikan-instansi-vertikal.html }}$ 
Social empowerment affairs practiced by the Office of Social Affairs of West Java Province have been conducted in accordance with the mandate of the Law No. 23 of 2014 on Regional Government. Social empowerment covers two main affairs, namely the issuance of permits regarding cross-regional contributions collection in the area of the province and the empowerment of the potential sources of social welfare of the province.

\section{Issuance of permits regarding cross-regional contributions collection in 1 (one) of province.}

Nowadays the affair of issuing permits of cross-regional social contribution across the regions in West Java Province has been handed over to the One-Door Integrated Services (Pelayanan Terpadu Satu Pintu/PTSP). Office of Social Affairs of West Java Province only issues permits for social welfare institutions or foundations which are located under its operational regions both on provincial and regional level.

\section{The empowerment of the potential sources of social welfare of the province.}

Service targets of the development of social welfare are individuals, families, groups or communities who are financially less fortunate or experience both physical and social barriers and are called people with social welfare problems (Penyandang Masalah Kesejahteraan Sosial/PMKS), as well as people who are able to perform the efforts of managing social welfare problems and are included in the group of the Social Welfare Potential and Sources (Potensi dan Sumber Kesejahteraan Sosial/PSKS). As a result of the monetary crisis, the extended economic crisis and various government policies in the economy, the number of population of PMKS tends to increase. Data validation from all districts/cities across the province West Java done in 2012 showed the number of PMKS of 6,444,173. There were changes in PSKS data validation results in 2012, which show changes in the level of participation or community awareness of social welfare problems. In regard to the empowerment of the PSKS group, Office of Social Affairs of West Java Province has the Social Work Training Center (Balai Pelatihan Pekerjaan Sosial/BPPS) in Cibabat, Cimahi. The tasks of BPPS are as follows:

1. To carry out the preparation of the work programs of the porch of the Social Work Training Center (Balai Pelatihan Pekerjaan Sosial/BPPS) Cibabat-Cimahi;

2. To study the technical guidance materials on the training of social workers;

3. To conduct trainings for social workers, including the development of training and conducting trainings for social workers, social volunteers, the organizers of social welfare and professional social workers;

4. To provide facilitation related to social workers trainings;

5. To manage the administration of Social Work Training Center (BPPS) Cibabat-Cimahi;

6. To conduct a study on staff as considerations for policy making;

7. To coordinate with related work units;

8. To conduct evaluation and reporting; and

9. To carry out other duties in accordance with the main tasks and functions

In the case of the empowerment of PSKS in West Java Province, the Office of Social Affairs often comes across authority overlaps in the provision of social services. For example there are two institutions whose authority overlaps with the Office of Social Affairs, namely Agency of Women Empowerment, Children Protection and Family Planning (Badan Pemberdayaan Perempuan Perlindungan Anak dan Keluarga Berencana/BP3KB) and Regional Disaster Mitigation Agency (Badan Penanggulangan Bencana Daerah/BPBD). For example, in the case of human trafficking, although it is dealt with by BP3KB but it is also taken care of by the Office of Social Affairs. Then, when a disaster strikes, even though it is taken care of by BPBD but this affair is also under the authority of the Office of Social Affairs. In the case of disasters, the Office 
of Social Affairs deploys special officers in charge of disaster mitigation called Tagana (Tanggap Bencana/Disaster Response) officers. But BPBD also have special officers called BPDB officers. On field, what distinguish them are the vests or uniforms that they wear. Another problem that is often encountered is that a Tagana officer from the Office of Social Affairs and a BPBD officer turn out to be the same person. In this case, it can be concluded that there are PSKS with double functions. The Office of Social Affairs needs to address this issue so that in the future there will be no more PSKS with double jobs.

The management of migrant citizens who are victims of violence has been in accordance with the Law No. 23 of 2014 on Regional Government, which states that it is within the authority of the provincial Office of Social Affairs to refer the victims to the regional Office of Social Affairs. The regional Office is then authorized to send the victims back to their respective families. Prior to their return to their respective families, the victims will first undergo rehabilitation first in Social Rehabilitation Center of Community Development (Balai Rehabilitasi Sosial Bina Karya/BRSBK) in Cisarua, Western Bandung. This is done to condition the victims back to normalcy before they return to their respective families. The Social Rehabilitation Center (BRSBK) in Cisarua supervises two rehabilitation houses, namely the House of Self-Support Social Rehabilitation (Rumah Rehabilitasi Bina Mandiri/RRSBM) Cirebon and Shelter House (Rumah Singgah) Caringin Bandung.

The Office of Social Affairs of West Java Province also provides service of social rehabilitation for former victims of substance abuse, people with Human Immunodeficiency Virus/Acquired Immuno Deficiency Syndrome that require rehabilitation in orphanages. For the provision of this service, the Office of Social Affairs of West Java Province has the Pamardhi Putra Social Rehabilitation Center (Balai Rehabilitasi Sosial Pamardhi Putra/BRSPP) in Lembang, Western Bandung whose main task is carry out some functions of the Office of Social Affairs of providing social rehabilitation for the victims of narcotics, psychotropic drugs and other substances abuse. The function of BRSPP is to study the technical guidance materials of social rehabilitation for substance abuse victims and to provide services and social rehabilitation for substance users.

\section{Social protection and security \\ Issuance of permits for foster parents for adoption of children between Indonesian citizens and adoption of children by single parents.}

Issuance of foster parents or adoption permits has also been conducted in accordance with the Law No. 23 of 2014 and is carried out at the provincial level by the Office of Social Affairs of West Java Province.

As for poverty and underprivileged children, the Office of Social Affairs of West Java Province has submitted the issues into Program Keluarga Harapan/PKP. This is based on considerations that it will be better for underprivileged children to stay in orphanages; likewise, it is better for the elderly people to be taken care of in nursing homes. In the case where the children or the elderly still have families, the Office of Social Affairs of West Java Province will seek to return the children or the elderly to their respective families. It is because being taken care of by their families is essentially better than being in orphanages or nursing homes. In some cases, if there is an elderly being left to be taken care of in nursing homes while they still have a family, the Office of Social Affairs will directly recommend them to be taken care of by their family.

\section{Data management of the poor people in provinces.}

The Law states that the province has the authority in the data formation of the poor people on provincial level whereas the president has declared that the data related to poverty should 
come from one source that is the Ministry of Social Affairs, which means that if it has been managed by the Ministry of Social Affairs, then the data has included Aid Recipients of National Health Insurance (Penerima Bantuan Iuran Jaminan KesehatanNational/PBIJKN) that consist of Kartu Indonesia Pintar/KIP, Kartu Indonesia Sehat/KIS and Kartu Kesejahteraan Sosial/KKS (Social Welfare Card). With the existence of a single source the Ministry of Social Affairs hopes to avoid double entries of data. The source for the Ministry of Social Affairs to arrange the data comes from Statistics Indonesia (Badan Pusat Statistik/BPS) and Local Development Planning Agency (Badan Perencanaan Pembangunan Daerah/BAPPEDA) and is administered by Regional Technical Implementation Unit (Unit Pelaksana Teknis Daerah/UPTD). This time the data has become special data of Social Welfare Information System (Sistem Informasi Kesejahteraan Sosial/SIKS) for Program Keluarga Harapan/PKH, Community Health Insurance (Jaminan Kesehatan Masyarakat/Jamkesmas), Kartu Indonesia Sehat/KIS and Kartu Indonesia Pintar/KIP. The data has been compiled by name by address all throughout Indonesia. The Governor of West Java has also formed a special team to take care of the poor in the regions. With the existence of this team, the management of the poor people in West Java Province is done across sections.

\section{The Disaster Management}

The provision of basic needs and trauma recovery for provincial disaster victims.

This is done specifically by the Tagana officers deployed by the Office of Social Affairs of West Java Province.

\section{The Heroes Cemetery Maintenance of the National Heroes cemetery in provinces.}

The management of heroes cemetery specifically poses some problems for the Office of Social Affairs, because the asset of the cemetery itself does not belong to the province but belongs to the Indonesian Army (TNI). But so far, the affairs of maintenance and care as well as coordination with related parties have been done by the Office of Social Affairs of West Java Province as an extension of the Provincial Government of West Java. Management of the cemetery is assigned to a special institution under the authority of the Office of Social Affairs of West Java Province named Tresna Wherda Social Protection Agency (Badan Perlindungan Sosial Tresna Wherda/BPSTW).

The fact that heroes cemetery is an asset owned by the Indonesian Army proves an obstacle to the management of its maintenance budget. The Office of Social Affairs of West Java Province has tried to encourage the Ministry of Finance in the Directorate of Assets to hand over the ownership of the cemetery on the provincial and regional levels to the Office of Social Affairs. Some of the problems identified based on the results of research are summarized in the table below: 
Table 1. Problems of the Authority Implementation of the Mandatory Affairs Related to Basic Services in the Province of West Java

\begin{tabular}{|c|c|c|}
\hline No & The Office & Problems Finding \\
\hline 1. & Office of Education & $\begin{array}{l}\text { - The handover of the education affairs } \\
\text { (SMA/SMK) to the provincial authority } \\
\text { - Education Management can be implemented well } \\
\text { - The curriculum can be developed well; } \\
\text { - The additional burden for the provincial } \\
\text { Employment Agency to manage the educators } \\
\text { and educational staff. }\end{array}$ \\
\hline & Office of Health & $\begin{array}{l}\text { The handover of authority when } \\
\text { regencies/municipalities are not able to provide health } \\
\text { services. }\end{array}$ \\
\hline 3. & $\begin{array}{l}\text { Office of Highways } \\
\text { and Spatial Planning }\end{array}$ & $\begin{array}{l}\text { - The shortage of human resources in exercising } \\
\text { the authority. } \\
\text { - Marine spatial planning must follow land spatial } \\
\text { planning. }\end{array}$ \\
\hline & $\begin{array}{l}\text { Office of Housing and } \\
\text { Settlement }\end{array}$ & $\begin{array}{l}\text { The central government has not defined the standards } \\
\text { and the criteria in the Law No. } 23 \text { of } 2014 \text {. }\end{array}$ \\
\hline 5. & $\begin{array}{l}\text { Office of National } \\
\text { Unity and Politics }\end{array}$ & $\begin{array}{l}\text { Excess authority which results on the overlapping of } \\
\text { authority. }\end{array}$ \\
\hline & Office of Social Affairs & $\begin{array}{l}\text { Law No. } 23 \text { of } 2014 \text { does not synchronize with } \\
\text { legislation on social welfare. }\end{array}$ \\
\hline
\end{tabular}

\section{CONCLUSION}

The implementation of authority of the central, provincial and regional governments is based on the division of government affairs. Based on Law No. 23 of 2014 on Regional Government, government affairs are divided into absolute affairs, concurrent affairs and general government affairs. The implementation of absolute affairs is fully under the authority of the central government, whereas general government affairs are under that the authority of the president as the head of government. Concurrent affairs are joint affairs that are divided into the authority of the central, provincial and regional governments. The division of concurrent affairs as joint affairs has been regulated in Law No. 23 of 2014 on Regional Government, but in practice it still imposes various problems related to authority, such as: the complete lack of authority; authority arbitrariness; authority overlap; half-hearted authority; authority takeover; arbitrary or abused authority and the lack of authority.

\section{BIBLIOGRAPHY}

Atmosudirdjo, Prajudi. 1981. State Administration Law, Jakarta: Ghalia Indonesia

Aziz, A. and D.D. Arnold. 1996. Decentralized Governance in Asian Countries, London: Sage Publications

Chalid, Pheni. 2005. Local autonomy: Problem, Empowerment and Conflict, Jakarta: Kemitraan

Shabbir Cheema, G., and Dennis A. Rondinelli,. 1983, Decentralization and Development: Policy Implementation in Developing Countries, Beverly Hills California: Sage Publication

Cohen, J and Peterson S.B. (Eds).1999. Administrative Decentralization, Strategies for Developing Countries, West Hartford: CT Kumarian Press

Dahl, Robert. 1982 Dilemmas of Pluralist Democracy: Autonomy Vs. Control, Yale University Press, New Haven Deliarnoor, Nandang Alamsah. 2017. Rule of Law, Bandung: Unpadpress

Devas, N. 1989. Financing Local Governments in Indonesia. Ohio: Ohio University Center for International Studies, Monographs in International Studies, Southeast Asian Series 
Hadjon, Philipus M. et al.1994. Introduction to Administrative Law in Indonesia, Yogyakarta : Gajah Mada University Press

Juanda airport. 2008. The Law of Regional Government: The Tides in Authority Connections between the Local Parliament and Regional Head, Bandung. Pt Alumni

Litvack,J, Achmad, J, and Bird, R.1998. Rethinking Decentralization in Developing Countries, Washington D.C: The World Bank

Bagir Manan,. 2004. The Authority of the Provinces, Districs and Cities on Local Autonomy. Jakarta: Pustaka Sinar Harapan

Mardiasmo. 2002. Local Autonomy and Regional Financial Management. Yogyakarta: Publisher Andi

Muljadi, M.Arief. 2005. The Foundation and Law Principles of Local Autonomy in the Unitary State Of The Republic of Indonesia, Jakarta : Prestasi Pustaka

Ridwan HR. 2006. State Administrative Law . Jakarta: RadjaGrafindo Persada

Said, Mas'ud. 2008. New Directions of Local autonomy in Indonesia. Malang: UMM Press

Sarundajang, SH.2011. The Reverse Flow of Central to Regional Authority. Jakarta: Kata Hasta Pustaka

Smith, B.C. 1985. Decentralization, The Territorial Dimension of The State, George London: Allen and Unwim Syaukani, HR, Ibn Afan Gaffar, Ryaas Rasyid. 2002. Local Autonomy in A Unitary State. Yogyakarta: Pustaka Pelajar.

The Turner, M and O. Podger (eds). 2003. Decentralization in Indonesia, Redesigning The State, Asia Pacific Press at The ANU, Canberra

Widjadja, H.A.W. 1996. Models of Local Autonomy in Indonesia. Palembang : Rineka Cipta.

Widjadja, H.A.W. 2007. Implementation of Local Autonomy in Indonesia for the Socialization of Law No. $32 / 2004$ on Regional Government. Jakarta : Raja Grafindo Persada.

The World Bank. 1999. Entering 21 st century, Decentralization; Rethinking Government, The World Development Report 1999/2000, New York: Oxford University Press

Joseph, Purnomo Dwi Warlan.1997. The Development Institutions, Bandung: Parahyangan University. 